Editor Office : LPPM Sekolah Tinggi Teknologi Pagar Alam, Jln. Masik Siagim No. 75
Simpang Mbacang, Pagar Alam, SUM-SEL, Indonesia
Phone : +62 852-7901-1390.
Email : ngabdimas@,1ppmsttpagaralam.ac.id | ejournal@1ppmsttpagaralam.ac.id
Website : https://ejournal.lppmsttpagaralam.ac.id/index.php/ngabdimas

\title{
Pelatihan Modul Pembelajaran Menggunakan MS. Word Bagi Guru SMP Dan Sma Di Pulau Pinang Lahat
}

\author{
Alfis Arif ${ }^{1}$, Risnaini Masdalipa ${ }^{2}$ \\ ${ }^{12}$ Program Studi Teknik Informatika; Sekolah Tinggi Teknologi Pagaralam (STTP) \\ Jl. M. Siagim No.75 Kel. Karang Dalo, Dempo Tengah, Kota Pagar Alam \\ Telp/Fax: (0730) 621916
}

e-mail: alfisarif@yahoo.com ${ }^{1}$, risnainipga@gmail.com ${ }^{2}$

\begin{abstract}
Abstrak
Modul pembelajaran yang baik dan menarik menjadi sarana pembelajaran yang juga menambah semangat peserta belajar untuk mempelajari pelajaran yang diberikan, sehingga agar modul menjadi menarik dan bagus harus digunakan sarana pembuat modul juga yang baik dan pembuat modul memiliki kemampuan yang baik menuangkan ide sehingga menjadi modul yang bagus, SMPN dan SMAN di Pulau Pinang Lahat bersama civitas STTP yang mengadakan pengabdian melakukan pelatihan pembuatan modul pembelajaran yang baik menggunakan Ms. Word bagi Guru, Pelatihan yang dilakukan menggunakan metode ceramah secara langsung dilanjutkan dengan praktek, praktek dilakukan dengan membuat desain, layout dan editing data menggunakan word sehingga modul menjadi lebih menarik, supaya pelatihan berjalan dengan baik maka sebelum pelatihan dilakukan tes untuk mengetahui pemahaman peserta dengan pembuatan modul menggunakan word, hasilnya $60 \%$ peserta belum lancar menggunakan dan mengedit data menggunakan word sehingga pelatihan baik untuk dilaksanakan, setelah pelatihan dilakukan juga tes untuk mengetahui tingkat keberhasilan dari pelatihan yang dilakukan dan hasilnya peserta 100\% mampu mengolah data dan mengedit menggunakan word sehingga pada saat aplikasi untuk modul sederhana dan hasilnya baik.
\end{abstract}

Kata kunci-Modul, Pelajaran, Guru, Desain, Word.

\section{PENDAHULUAN.}

Semangat berbagi sesama dalam membangun dan mengembangkan kehidupan untuk kesejahteraan bersama menjadi suatu hal yang terus dipupuk oleh civitas Sekolah Tinggi Teknologi Pagaralam (STTP). Perkembangan teknologi informasi dan komunikasi khususnya teknologi yang mendukung Media pembelajaran saat ini sangat banyak dan menawarkan kemudahan-kemudahan sesuai ke unggulannya masing-masing, salah satunya Ms. Word yang bisa di manfaatkan sebagai sarana pembuatan modul.Media ini sangat banyak sekali digunakan di sebagai sarana pengolahan data yang sangat familiar.

Penggunaan Ms. Word sebagai media/sarana pembuatan modul ini sangat di sarankan karena memiliki menu-menu yang sesuai dengan standar penulisan yang di sarankan oleh para ahli yang kompeten, sehingga pada saat penyusunan pada Ms. Word ini penulis tinggal klik menu-menu yang di maksud maka akan di dapat hasil tulisan yang baik (standar), selain itu Ms. Word merupakan software pengolah kata/data yang include dalam software dalam sistem komputer dan biasanya benar-benar atau merupakan software asli yang di buat oleh Microsoft sehingga tidak akan ditemui bagian menu yang rusak (crash), selain itu apa bila ingin meng-upgrade, atau mengganti ke versi terbaru Microsoft menyediakan dengan mudah. Dari pemaparan diatas dituntu agar para Guru bidang studi harus selalu meningkatkan kualitas pembelajaran dengan menggunakan semua resource terkait, sehingga dipandang perlu untuk diadakan pelatihan pembuatan modul pembelajaran ini. Modul merupakan sarana menampung materi pelajaran dalam sesuatu berbentuk seperti buku, agar bisa dimanfaatkan dan pelajaran yang disampaikan dapat dipelajari lagi oleh pelajar dimana saja dengan menggunakan modul, modul yang baik tentu diolah menggunakan 
sarana yang baik juga, pada pelatihan ini sarana yang dipergunakan adalah Microsoft office word, sehingga pelatihan dilakukan bagi Guru SMP dan SMA di Kec. Pulau Pinang.

\section{METODE.}

Metode pelaksanaan pengabdian dilakukan mandiri oleh civitas akademika STTP dibawah koordinasi LPPM STTP. Dilakukan dengan menggunakan secara langsung dan banyak dilakukan dengan pendekatan praktek secara langsung dengan cara menyimak (menonton) bersama, membaca bersama (modul pelatihan), memahami tools aplikasi (Software) dan berinteraksi secara langsung (Aplikatif) dengan software. Sehingga diyakini peserta pelatihan memahami materi dengan sangat baik dan mampu mengaplikasikan kembali pemahamannya untuk keperluannya.

\subsection{Pengabdian Pada Masyarakat (PkM).}

Pengabdian, suatu kegiatan yang bertujuan membantu masyarakat dalam beberapa aktivitas tanpa mengharapkan imbalan berbentuk apapun. Umumnya program ini dirancang oleh berbagai universitas yang ada di Indonesia untuk memberikan kontribusi nyata bagi bangsa, khususnya dalam mengembangkan kesejahteraan dan kemajuan bangsa. Pengabdian Masyarakat merupakan satu bagian dari Tri Dharma Perguruan Tinggi. Bentuk-bentuk kegiatan Pengabdian Masyarakat, biasanya berupa: Bakti Sosial dan Mengajar. Tujuan Pengabdian di Perguruan Tinggi, adalah:

1. Meningkatkan \& ciptakan inovasi teknologi informasi untuk mendorong pembangunan ekonomi dengan melakukan komersialisasi hasil penelitian, yang dilakukan dikampus;

2. Menyajikan solusi berdasarkan kajian program akademik atas kebutuhan, tantangan, atau persoalan yang dihadapi masyarakat, baik secara langsung maupun tidak langsung;

3. Melaksanakan kegiatan yang bisa mengentaskan masyarakat tersisih (preferential option for the poor) di semua strata, yakni masyarakat tersisih secara ekonomi, politik, sosial \& budaya;

4. Melakukan alih teknologi informasi, ilmu \& seni pada masyarakat untuk pengembangan martabat manusia dan kelestarian SDA.

\subsection{Modul Pembelajaran.}

Modul pembelajaran merupakan satuan program belajar mengajar terkecil, yang dipelajari siswa sendiri secara perseorangan atau diajarkan siswa kepada dirinya sendiri (self-instructional) (Winkel, 2009:472). Modul pembelajaran yaitu bahan ajar disusun secara sistematis dan menarik mencakup isi materi, metode dan evaluasi yang bisa digunakan secara mandiri untuk mencapai kompetensi diharapkan (Anwar, 2010). Menurut Goldschmid, Modul pembelajaran sebagai sejenis satuan kegiatan belajar terencana, di desain guna membantu siswa menyelesaikan tujuan-tujuan tertentu. Modul adalah semacam paket program untuk keperluan belajar (Wijaya, 1988:128).

Vembriarto (1987:20) menyatakan bahwa suatu modul pembelajaran, suatu paket pengajaran memuat unit konsep dari bahan pelajaran. Pengajaran modul merupakan usaha penyelanggaraan pengajaran individual memungkinkan siswa menguasai unit bahan pelajaran sebelum dia beralih pada unit berikutnya. Berdasarkan beberapa pengertian modul diatas maka bisa disimpulkan bahwa modul pembelajaran salah satu bentuk bahan ajar dikemas secara sistematis dan menarik sehingga mudah untuk dipelajari secara mandiri.

\section{Ciri-ciri/ Karakteristik Modul}

Modul pembelajaran merupakan salah satu bahan belajar yang bisa dimanfaatkan siswa secara mandiri. Modul baik harus disusun secara sistematis, menarik \& jelas. Modul bisa digunakan kapan pun dan dimana pun sesuai dengan kebutuhan siswa. Anwar (2010), menyatakan karakteristik modul pembelajaran sebagai berikut:

1. Self instructional, Siswa mampu membelajarkan diri sendiri, tak tergantung pada pihak lain.

2. Self contained, Seluruh materi pembelajaran dari satu unit kompetensi yang dipelajari terdapat didalam satu modul utuh.

3. Stand alone, Modul yang dikembangkan tidak tergantung pada media lain atau tidak harus digunakan bersama-sama dengan media lain.

4. Adaptif, Modul hendaknya memiliki daya adaptif tinggi terhadap ilmu dan teknologi.

5. User friendly, Modul hendaknya memenuhi kaidah akrab bersahabat/akrab dengan user.

6. Konsistensi, Konsisten dalam penggunaan font, spasi dan tata letak. 
Menurut Wijaya (1988:129), ciri-ciri pengajaran modul pembelajaran adalah :

1. Siswa bisa belajar individual, ia belajar dengan aktif tanpa bantuan maksimal guru.

2. Tujuan pelajaran dirumuskan khusus. Rumusan tujuan bersumber perubahan tingkah laku.

3. Tujuan dirumuskan khusus hingga perubahan tingkah laku terjadi pada diri siswa segera bisa diketahui. Perubahan tingkah laku diharapkan 75\% penguasaan tuntas (mastery learning).

4. Membuka kesempatan siswa untuk maju berkelanjutan menurut kemampuan masing-masing.

5. Modul merupakan paket pengajaran bersifat self-instruction, dengan belajar seperti ini, modul membuka kesempatan pada siswa untuk mengembangkan dirinya secara optimal.

6. Modul memiliki daya informasi cukup kuat. Unsur asosiasi, struktur dan urutan bahan pelajaran terbentuk sedemikian rupa sehingga siswa spontan mempelajarinya.

7. Modul banyak memberikan kesempatan kepada siswa untuk berbuat aktif.

\section{Kelemahan Pembelajaran dengan Menggunakan Modul}

Belajar menggunakan modul disebut belajar mandiri. Menurut Suparman (1993:197), menyatakan bentuk kegiatan belajar mandiri ini mempunyai kekurangan sebagai berikut :

1. Biaya pengembangan bahan tinggi dan waktu dibutuhkan lama.

2. Menentukan disiplin belajar tinggi, mungkin kurang dimiliki siswa pada umumnya dan siswa yang belum matang pada khususnya.

3. Memerlukan ketekunan lebih tinggi dari fasilitator untuk terus mamantau proses belajar siswa, memberi motivasi dan konsultasi secara individu tiap waktu siswa memerlukan.

Tjipto (1992:72), mengungkapkan hal memberatkan belajar menggunakan modul, yaitu :

1. Kegiatan belajar memerlukan organisasi yang baik.

2. Proses belajar perlu diadakan beberapa ulangan/ujian, perlu dinilai sesegera mungkin

Sesuai pendapat di atas bisa disimpulkan bahwa pembelajaran menggunakan modul juga memiliki beberapa kelemahan mendasar yaitu memerlukan biaya yang besar serta memerlukan waktu yang lama dalam pengadaan atau pengembangan modul itu sendiri, dan membutuhkan ketekunan tinggi dari guru sebagai fasilitator untuk terus memantau proses belajar.

\section{Kelebihan Pembelajaran Menggunakan Modul.}

Belajar menggunakan modul banyak manfaatnya, siswa bisa bertanggung jawab terhadap kegiatan belajar sendiri, pembelajaran dengan modul sangat menghargai perbedaan individu, sehingga siswa bisa belajar sesuai tingkat kemampuannya, maka pembelajaran efektif \& efisien. Tjipto (1991:72), mengungkapkan keuntungan yang diperoleh jika belajar menggunakan modul, antara lain :

1. Motivasi siswa dipertinggi karena tiap siswa mengerjakan tugas pelajaran dibatasi dengan jelas dan yang sesuai kemampuannya.

2. Sesudah pelajaran selesai guru dan siswa mengetahui benar siswa yang berhasil dengan baik dan mana yang kurang berhasil.

3. Siswa mencapai hasil yang sesuai dengan kemampuannya.

4. Beban belajar terbagi lebih merata sepanjang semester.

5. Pendidikan lebih berdaya guna.

Santyasa (Suryaningsih, 2010:31), menyebutkan keuntungan yang diperoleh pembelajaran dengan penerapan modul, sebagai berikut:

1. Meningkatkan motivasi siswa, karena setiap kali mengerjakan tugas pelajaran yang dibatasi dengan jelas dan sesuai dengan kemampuan.

2. Setelah dilakukan evaluasi, guru \& siswa mengetahui benar, pada modul yang siswa telah berhasil dan pada bagian modul yang mereka belum berhasil.

3. Bahan pelajaran terbagi lebih merata dalam satu semester.

4. Pendidikan lebih berdaya guna, karena bahan pelajaran disusun menurut jenjang akademik.

\section{3. $\quad$ Edit Word.}

Orang ketika mengerjakan tugas dengan anggota kelompok menghabiskan banyak waktu untuk 'menunggu giliran' mengedit satu dokumen yang sama. Belum lagi harus mengunduh banyak file sebetulnya sama (hanya sedikit berbeda di bagian tertentu) dengan nama yang bertumpuk untuk bisa digabungkan menjadi dokumen utuh, seperti 'file tugas 1 bagian boc.doc', 'file tugas 1 bagian bill.doc', 'file tugas 1 bagian dull.doc.' Ini hanya membuat folder berantakan dan 
membingungkan saat pengerjaan tugas. Untungnya, Microsoft Word menawarkan alternatif gratis untuk permasalahan ini. Software populer ini memungkinkan penggunanya untuk mengedit file yang sama secara bersamaan. Asal perangkat terhubung internet, fasilitas ini bisa dimanfaatkan. Dilansir dari laman resminya, mengklaim fasilitasnya ini dapat membuat pekerjaan kelompok jadi cepat dan bisa diakses di tiga versi Word, yakni Word 2010, Word 2013, dan Word for Mac 2011. Berikut langkah agar dokumen Word dapat diedit secara bersamaan beberapa orang.

a. Save file dokumen dalam OneDrive atau Share Point Online, klik file > save as.

b. Selanjutnya cari tombol 'Share' untuk membagi file pada alamat email anggota kelompok.

c. Tetapkan izin mengakses anggota dengan meng-klik "Can edit" (selected by default).

d. Masukan pesan jika diperlukan, lalu pada perintah "Automatically share changes" klik "Always." Perintah "Always" membuat setiap anggota bisa melihat perubahan dokumen secara real time tepat saat anggota lain mengedit.

e. Klik Share.

f. Ketika anggota kelompok yang diundang mengklik link yang terkirim melalui email mereka, dokumen terbuka pada versi Word atau Word Online jika tidak menginstal program Word di desktop. Mereka hanya perlu memberikan perintah izin untuk bisa mengakses dokumen dan melakukan editing real time. Anggota bisa melihat jumlah anggota lain, dan aktivitas seperti masuk atau meninggalkan dokumen.

Gangguan biasa muncul seperti anggota tak bisa mengakses link yang dibagikan. Menurut Support Office, untuk permasalahan ini pastikan tidak memberikan perintah pada dokumen yang mencegah penulis lain mengedit dokumen di Word untuk web. Misal, jangan gunakan fitur izin seperti pembatasan pengeditan atau menandai dokumen sebagai final. Jika ingin membatasi akses ke dokumen, gunakan fitur izin tempat dokumen disimpan (OneDrive, Office 365, atau SharePoint). Selain itu pastikan sambungan internet di kondisi baik agar bisa mendukung pengerjaan ini.

\subsection{Word Office.}

Pengolah kata seperti Microsoft Word merupakan aplikasi yang populer. Walaupun ketika anda melamar pekerjaan, memahami Microsoft Word mungkin tak menjadi kewajiban, namun sangat penting bagi kita untuk memiliki kemampuan dasar. Dan di artikel ini, anda mempelajari langkah belajar Microsoft Word dengan cepat.

\section{Hal-hal bisa dibuat dengan Microsoft Word}

Microsoft Word, aplikasi ini melakukan banyak hal. Karena Microsoft Word aplikasi pengolah kata, berarti anda berurusan dengan semua hal berbentuk kata, kalimat \& paragraf. Berikut beberapa hal yang bisa buat dengan Microsoft Word sebagai gambaran untuk mempelajarinya:

- Buat berbagai jenis dokumen misal proposal, makalah \& dokumen besar seperti buku \& novel

- Membuat sertifikat, data yang special dan khusus.

- Membuat kartu ucapan, kartu nama dan sejenisnya.

- Membuat brosur, pamflet, dan beberapa macam media iklan dasar lainnya.

- Membuat absensi, surat, dan sejenisnya.

- Dan berbagai macam jenis media kertas lainnya.

Apapun pekerjaan, kemungkinan besar anda diminta menggunakan atau belajar Microsoft Word sangat besar. Untuk itu, berikut:

\section{Persiapan.}

Berikut merupakan hal yang perlu disiapkan sebelum mulai belajar Microsoft Word:

\section{Menginstall Microsoft Office 2016/2019/365}

Pengabdi memanfaatkan Microsoft Office 365 menulis ini dengan update yang baru. Sebagai rekomendasi, versi Office minimal yang digunakan Microsoft Office 2010 atau yang paling baru. Jika menggunakan Office 2007 atau Office 2003, terlalu banyak fitur yang tertinggal, sehingga disarankan agar menggunakan yang lebih baru. Walau artikel dibuat dengan Office 2016/365, tentu bisa mengikutinya jika menggunakan Office 2007 hingga Office 2013. Office 2003 tak didukung karena perbedannya sudah sangat jauh.

\section{Menggunakan satuan Centimeter.}

Saat buat dokumen, biasanya dihadapi dengan pengukuran. Microsoft Word secara default menggunakan inch. Di Indonesia, biasanya menggunakan Centimeter, sehingga perlu kita ubah 
dahulu dan agar sesuai dengan artikel belajar Microsoft Word kali ini. Cara mengubahnya klik File $>$ Options $>$ klik tab "Advanced"(1). Kemudian ke bagian "Display"(2). dan pilih "Centimeter" pada "Show measurements in units of:" (3). Klik OK jika sudah.

\section{Istilah-istilah yang digunakan di artikel ini}

Tulisan ini dibuat dengan studi kasus, dimana akan sama-sama mencoba dari awal, sehingga bukan hanya penjelasan, melainkan juga dengan praktek. Karena itu, perlu kita pelajari bersama istilah yang kita pakai untuk mempelajari Microsoft Word:

- Dokumen: Istilah yang gunakan untuk apapun tulisan yang dibuat. Jika membuat sertifikat, makalah, surat atau apapun itu, disebut sebagai dokumen.

- Tab: Istilah yang digunakan merujuk ke tab/menu di Microsoft Word. Ada 10 tab/menu seperti File, Home, Insert, Design, Layout, dan lain sebagainya.

Sehingga jika hal-hal dasar telah dilakukan maka berikut merupakan pembelajaran dasar untuk mengolah data menggunakan word:

\section{Mengatur Page Setup dan Margin}

Page Setup atau pengaturan halaman memungkinkan kita mengatur bagaimana bentuk halaman dimana kita membuat dokumen. Dalam mengaturnya, kita menggunakan satuan sebelumnya kita atur menjadi centimeter. Saat mengatur ukuran halaman atau dokumen, ada istilah dinamakan Margin, dimana bisa diatur berapa jarak dibutuhkan dari ujung halaman hingga isi dokumennya.

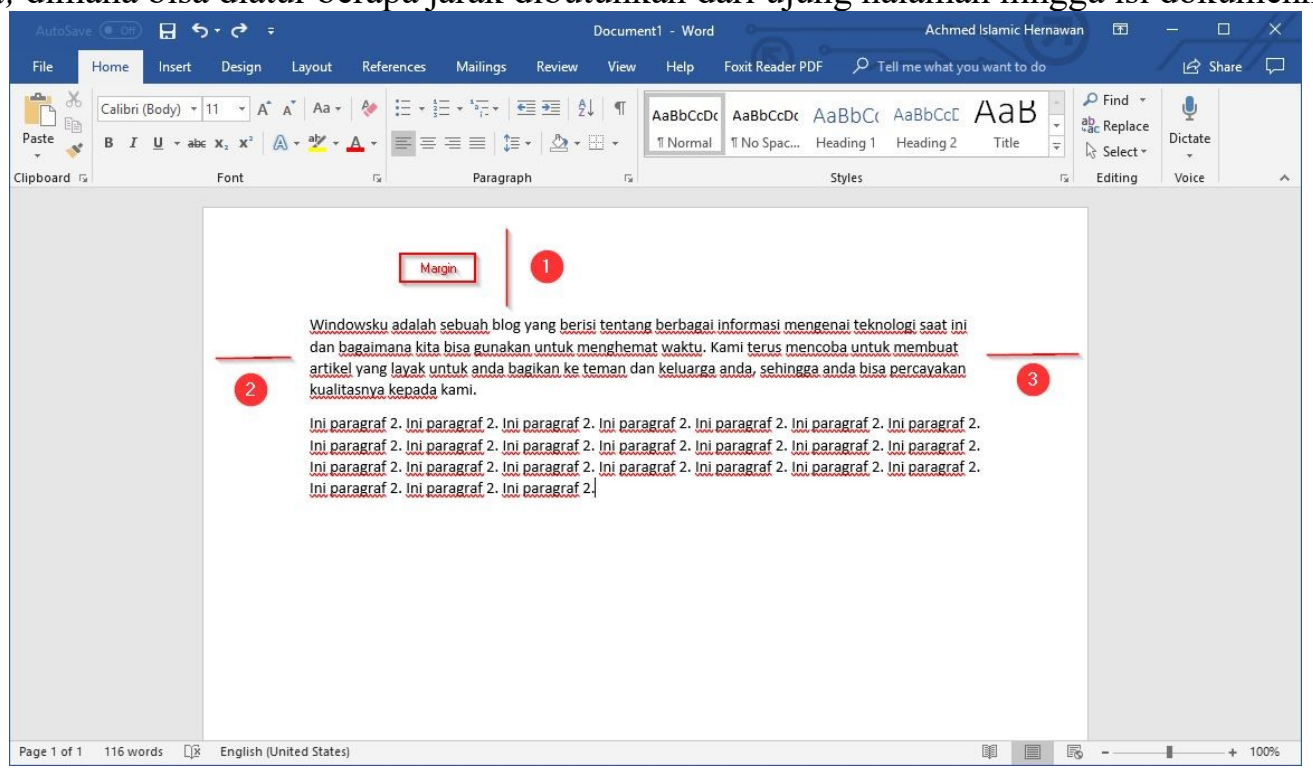

Margin bisa diatur di 4 tempat. Margin atas (1), margin kiri (2), dan margin kanan (3), serta margin bawah. Secara bawaan, margin-margin ini memiliki ukuran sebesar 2,54 cm di setiap sisinya.

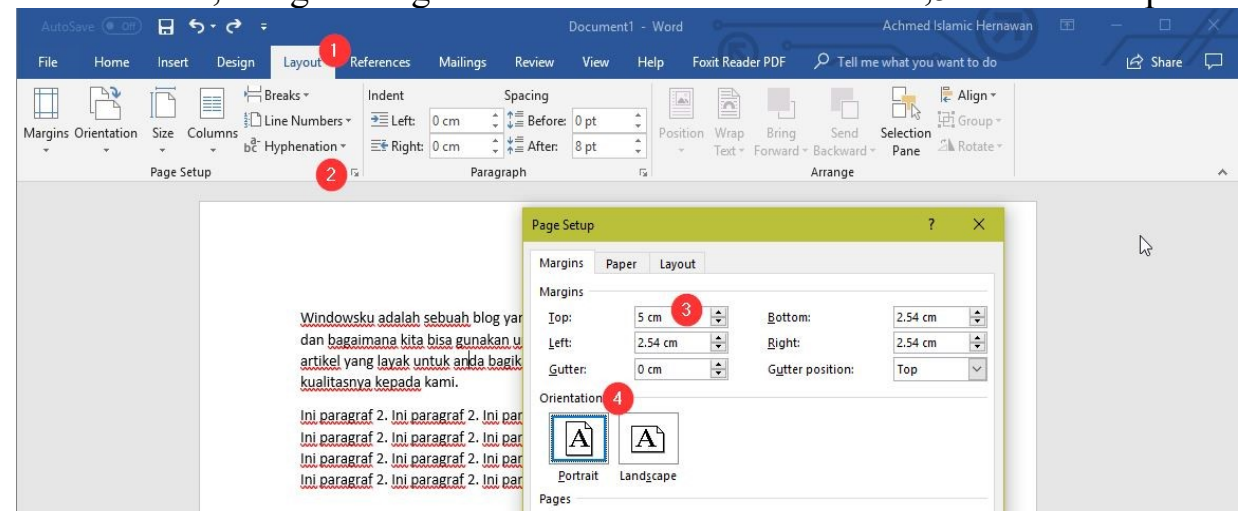

Mengubah ukuran margin, klik tab "Layout" (1) dan klik icon kecil disamping tulisan "Page Setup" (2). Bagian margin, pilih bagian yang ingin diubah ukurannya. Sebagai contoh, penulis mengubah ukuran margin top/atas sebesar $5 \mathrm{~cm}(3)$. Selain margin, juga bisa mengatur Orientasi, apakah memanjang/Portrait maupun melebar/Landscape (4). Jika sudah, klik OK. 


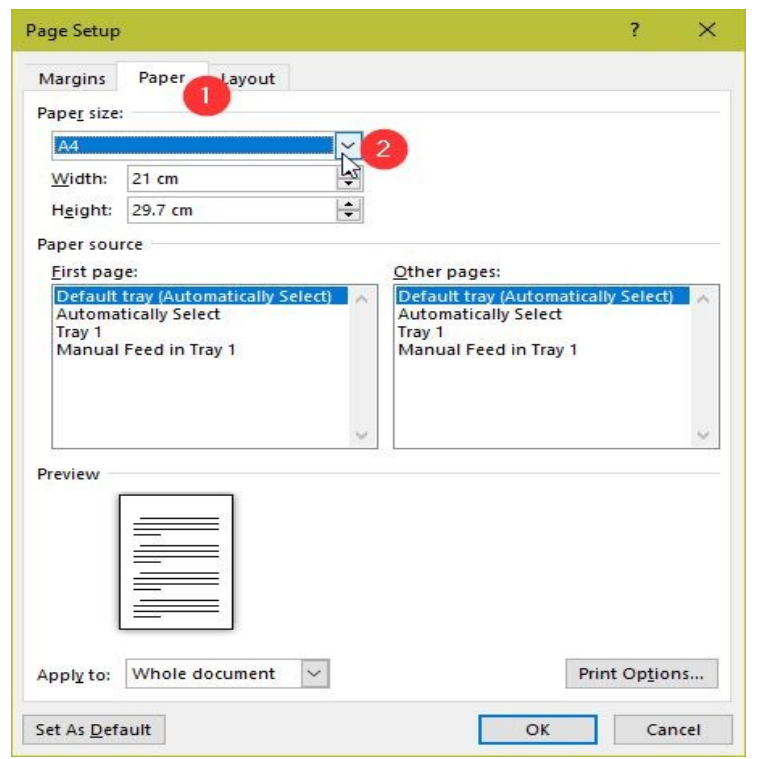

Selain margin, kita juga bisa mengatur jenis kertas. Kita perlu mengatur ini karena harus di sesuaikan ketika ingin mencetak dokumen. Tentu bisa mengaturnya belakangan dan tidak perlu harus diatur sekarang. Untuk mengubahnya, klik tab "Paper" (1) dan silahkan anda pilih jenis kertasnya di "Paper Size" (2).

\section{Pengelolaan paragraph.}

Mengatur paragraf, klik sekali terlebih dahulu paragraf yang ingin diubah. Klik tab "Home" (1) dan klik icon kecil disamping kanan "Paragraph" (2). Anda bisa memilih alignment (3) untuk mengatur arah tulisan paragraf. Indentation (4) berguna untuk memberikan jarak paragraf dari margin kiri dan kanan.Jika ingin menambahkan indent hanya dibaris pertama saja, gunakan "First line" (5) dan bisa mengatur berapa jarak indent-nya. Spacing (6) digunakan untuk mengatur jarak sebelum/before paragraf dan setelah/after paragraf. Klik OK jika sudah. Hasilnya sudah penulis terapkan seperti gambar diatas.

\section{Menggunakan Page Break.}

Caranya tekan tab "Insert", kemudian klik "Pages" dan klik "Page Break". Dengan cara ini, tidak perlu khawatir ketika menambah tulisan di halaman sebelumnya. Word secara otomatis mengisi ruang kosong tanpa perlu tulisan setelahnya terganggu.

\section{Header \& Footer dan Page Number}

Biasanya kita menggunakan hal ini untuk nomor halaman misalnya. Bagaimana caranya? Bisa dilakukan menggunakan Header \& Footer, anda bisa melakukan hal tersebut. Klik tab "Insert" (1) dan pilih antara header atau footer (2). Kemudian, pilih gaya yang anda inginkan (3). Dengan menggunakan Header \& Footer, penulis bisa menambahkan nomor halaman dengan mudah. Ketika membuat halaman baru, tentu nomor halaman juga tertulis secara otomatis. Selain Header \& Footer, klik "Page Number" untuk nomor halaman yang lebih sederhana tampilannya.

\section{Menambahkan gambar dan tabel beserta caption}

Gambar \& tabel sangat penting agar tampilan dokumen lebih menarik dan tak membosankan karena banyak paragraf. Selain gambar dan tabel, juga bisa diberikan caption atau deskripsi singkat mengenainya. Caption biasa didahului dengan nomor terlebih dahulu. Misal "Gambar 1. Windows" dan seterusnya. Tentu ketika menambah tabel atau gambar baru, nomor bertambah secara otomatis.

\section{a. Menambahkan gambar ke Microsoft Word}

Caranya sangat mudah, tinggal klik dan geser gambar dari File Explorer ke Microsoft Word seperti animasi. Atau, bisa mengklik tab "Insert" dan "Pictures" untuk memasukkan gambar. 


\section{b. Menambahkan tabel ke Microsoft Word}

Masih di tab "Insert" (1) dan klik "Table" (2) dan pilih ukuran yang sesuai kemauan (3). Jika ingin membuat tabel lebih besar lagi, bisa klik "Insert Table..." dan anda bisa tentukan berapa jumlah baris dan kolomnya.

\subsection{Pre \& Pos Tes.}

Pre tes yakni suatu bentuk pertanyaan, dilontarkan guru kepada murid sebelum memulai suatu pelajaran. Pertanyaan yang ditanya tentang materi akan diajar hari itu (materi baru). Pertanyaan itu biasanya dilakukan guru di awal pembukaan pelajaran. Pre tes diberikan untuk mengetahui apakah ada diantara murid sudah mengetahui mengenai materi akan diajarkan. Pre tes juga diartikan sebagai kegiatan menguji tingkatan pengetahuan siswa terhadap materi akan disampaikan, kegiatan pre tes dilakukan sebelum kegiatan pengajaran diberikan. Adapun manfaat dari diadakannya pre tes, untuk mengetahui kemampuan awal siswa mengenai pelajaran yang disampaikan. Dengan mengetahui kemampuan awal siswa ini, guru dapat menentukan cara penyampaian pelajaran yang di tempuh nanti.

Pos tes, bentuk pertanyaan diberikan setelah pelajaran/materi disampaikan. Singkatnya, pos tes sebagai evalausi akhir saat materi yang diajarkan hari itu telah diberikan yang mana seorang guru memberikan pos tes dengan maksud apakah murid mengerti dan memahami mengenai materi yang baru diberikan pada hari itu. Manfaat dari pos tes ini untuk memperoleh gambaran tentang kemampuan yang dicapai setelah berakhirnya penyampaian pelajaran. Hasilnya dibandingkan dengan hasil pre tes yang telah dilakukan sehingga diketahui seberapa jauh efek atau pengaruh dari pengajaran telah dilakukan, disamping sekaligus diketahui bagian mana dari bahan pengajaran yang masih belum dipahami siswa.

\subsection{Penyelesaian Masalah.}

Sarana pembelajaran yang baik atau ideal menjadi permasalahan yang harus diselesaikan dengan berat oleh sekolah-sekolah yang berada didaerah, karena keterbatasan sarana dan fasilitas yang dapat dimanfaatkan, fasilitas modul merupakan sarana andalan yang dikembangkan para guru SMP dan SMA di Kec. Pulau Pinang Kab. Lahat. Sarana lain semacam internet susah dilakukan karena jaringan tidak bagus, untuk keperluan ini maka harus dilakukan pelatihan pembuatan modul menggunakan MS. Word, maka pada kegiatan pelatihan ini atas kerja sama LPPM STTP dan Dinas Pendidikan Kec. Pulau Pinang. Pelatihan dilakukan dengan penyampaian materi teori tentang modul dan tata cara menulis yang baik, dilanjutkan denga praktek secara langsug pada Ms. Word dengan langsung praktek membuat modul.

\section{PEMBAHASAN DAN HASIL.}

3.1. Realisasi \& Pemecahan Masalah.

Realisasi dan penyelesaian masalah yang dihadapi para Guru SMP \& SMAN di Kec. Pulau Pinang, dilakukan dengan mengadakan pelatihan secara bersama-sama yang diselenggarakan dinas, bersama LPPM STTP dimana rincian kegiatannya sebagai berikut. Pertama, dilakukan tes, pre tes dilakukan untuk mengetahui tingkat pemahaman peserta pelatihan terhadap materi yang akan disampaikan pada pelatihan ini. Kedua, dijelaskan terlebih dahulu tentang pembuatan modul yang baik, dan yang menarik bagi pembacanya. Ketiga, kegiatan pembuatan modul dan praktek secara langsung dengan aplikasi Microsoft word, pada bagian ini para peserta diminta untuk mempraktekkan seluruh materi yang disampaikan pada saat pengantar materi modul disampaikan. Keempat, merupakan kegiatan terakhir pada kegiatan pengabdian yang dilakukan di SMP dan SMAN yang ada di Kec. Pulau Pinang Kab. Lahat merupakan tes terakhir atau pos tes dilakukan oleh narasumber yang manfaatnya adalah untuk mengetahui tingkat keberhasilan pelatihan pembuatan modul menggunakan Microsoft office word yang dilakukan.

Tabel 1. Kegiatan

\begin{tabular}{|c|l|l|}
\hline Waktu & \multicolumn{1}{|c|}{ Materi } & \multicolumn{1}{c|}{ Penyaji } \\
\hline $08.00-09.00$ & Pre Test & Alfis Arif \\
$09.00-09.30$ & Pengantar pembuatan modul & \\
\hline
\end{tabular}




\begin{tabular}{|l|l|l|}
\hline $09.30-12.00$ & $\begin{array}{l}\text { Praktek pembuatan modul dengan ms word dan diminta } \\
\text { mempraktekan membuat modul. }\end{array}$ & \\
$12.00-12.30$ & Ishoma & \\
$12.30-13.00$ & Post-test & \\
\hline
\end{tabular}

Maka berdasarkan langkah-langkah pelaksanaan pengabdian yang dilakukan diatas, dari metode pelaksanaannya yang dilakukan pada saat pengabdian ini, yang mana pelatihan dilakukan dengan seperti kegiatan seminar, dilakukan dengan menjelaskan materi tentang tata cara membuat modul yang baik dan yang menarik, dalam hal ini pembahasan adalah bagaimana mengedit dan mengevaluasi data menjadi modul yang mudah untuk dipelajari oleh para siswa peserta pelatihan sehingga kualitasnya modul sangat baik dan benar-benar mudah dipelajari, dimana struktur pelaksanaannya sesuai dengan tabel diatas, didahului dengan melaksanakan pre tes untuk memahami tingkat pemahamaan terhadap teori pembuatan modul dan pemahaman tentang teknologi seperti word untuk membuat modul, setelah dilakukan tes selanjutnya dilakukan persiapan pengolahan data buat modul apa saja dan bagimana menyiapkannya, persiapan ini melakukan pengenalan terhadap fitur-fitur Microsoft office word dan memberikan contoh bagaimana melakukan aplikasi terhadap fitur-fitur yang ada tersebut, sampai para peserta memahaminya seluruh fungsi dari fitur yang ada untuk digunakan pada saat melakukan editing data sehingga dihasilkan modul yang benar-benar menjadi familiar setelah dipelajari.

Seluruh peserta pelatihan menjadai sangat paham dan mengerti cara mengaplikasikan fiturfitur yang sudah ada dalam mengolah modul menjadi bahan (sarana) belajar yang baik, agar lebih baik lagi pemahaman para peserta pelatihan, dalam hal ini maka selanjutnya dilakukan pendampingan pengolahan secara langsung terhadap data modul yang dimiliki dengan aplikasi mengolah atau melakukan editing modul secara langsung, para peserta mengaplikasikan pemahamannya pada saat mengolah modul, dan narasumber secara langsung membimbing dan mendampingi para peserta melakukan editing modul yang dilakukan pada Microsoft office word, sehingga para peserta dengan mudahkan mengaplikasikan pelajaran secara langsung dan pada saat ada masalah atau kesulitan peserta pelatihan langsung bertanya pada pelatih atau narasumber secara langsung, sehingga peserta benar-benar paham dan benar-benar bisa melakukan editing modul dengan menggunakan aplikasi Microsoft office word.

Secara terstruktur dan terurut pelaksanaan pengabdian $(\mathrm{PkM})$ dilakukan sebenarnya pengabdi sudah menyakini bahwa peserta pelatihan Guru SMP \& SMAN Kec. Pulau Pinang telah memiliki pemahaman dan pengetahuan yang sangat baik dalam mengolah atau mengedit modul sarana pendukung pembelajaran, tetapi secara prosedur harus dilakukan tes lagi untuk dapat mengetahui lebih procedural tingkat pemahaman peserta dalam menyerap materi maka dilakukan pos tes, hasilnya $100 \%$ peserta pelatihan memahami materi dan pelatihan pengolahan data modul pembelajaran dengan sangat baik, yang mana pada awalnya mereka tidak memahami sama sekali tetapi metode belajar secara langsung pada aplikasi meningkatkan semangat peserta untuk belajar, dengan belajar secara langsung ternyata sangat mengena dengan keinginan peserta pelatihan yang dilaksanakan LPPM STTP dan Pihak Dinas Pendidikan.

\subsection{Pembahasan \& Hasil.}

Maka sesuai urutan pelaksanaan kegiatan pengabdian $(\mathrm{PkM})$ yang dilaksanakan diatas yang terdeskripsi didalam tabel 1. Maka berikut, merupakan uraian keberhasilan yang didapatkan dari pelaksanaan pengabdian $(\mathrm{PkM})$ yang dilaksanakan untuk tenaga pengajar atau Para Guru SMAN dan SMPN di Kec. Pulau Pinang Kab. Lahat sebagai berikut, dimana pada pelaksanaannya peserta pelatihan yang dilakukan harus diberikan pemahaman bukan hanya aplikasi tetapi juga pemahaman dasar tentang multimedia dan software-software pendukung lainnya yang mendukung dalam melakukan editing dan pengolahan data modul yang bagus sehingga modul belajar yang dihasilkan benar-benar menjadi sarana pembelajaran yang mudah dipelajari oleh para siswa dan siswi peserta pelatihan. Pada pelatihan ini dilakukan pre tes terlebih dahulu untuk mengetahui pemahaman peserta dalam pembuatan modul, dan menulis modul didalam Microsoft office word yang di pergunakan pada saat pelatihan dan hasilnya semua peserta cukup memahami modul dan tidak terlalu memahami aplikasi word terlalu baik, sehingga pada pelatihan ini pengantar pembuatan modul yang baik tetap disampaikan dan disampaikan lebih detail pengenalan Microsoft 
NGABDIMAS - Jurnal Pengabdian Kepada Masyarakat Vol. 03 No. 02 Desember 2020, Hal.41 -

office word terbaru dan penggunaan multimedia gambar yang lebih baik pada pelatihan ini sehingga modul yang dihasilkan menampilkan gambar-gambar inspiratif yang menarik.

Tabel 2. Keberhasilan Pelaksanaan Kegiatan

\begin{tabular}{|c|l|l|}
\hline Pertemuan & \multicolumn{1}{|c|}{ Materi } & \multicolumn{1}{c|}{ Hasil } \\
\hline 1 & Pendahuluan & $\begin{array}{l}\text { Peserta memahami tentang tujuan pengabdian dan } \\
\text { narasumber bisa mengarahkan materi pelatihan } \\
\text { sesuai dengan keperluan peserta, disebut Pre tes. }\end{array}$ \\
\hline 2 & Pengantar modul & $\begin{array}{l}\text { Peserta pelatihan memahami teknik membuat modul } \\
\text { dan membuat modul lebih menarik. }\end{array}$ \\
\hline 3 & Pengenalan Ms. Word & $\begin{array}{l}\text { Peserta memahami tools dan fitur yang membuat } \\
\text { modul menjadi menarik, memahami art \& sebagainya } \\
\text { sehingga modul menjadi lebih menarik. }\end{array}$ \\
\hline 5 & $\begin{array}{l}\text { Praktek pembuatan } \\
\text { modul }\end{array}$ & $\begin{array}{l}\text { Peserta mampu mengaplikasikan teori yang diberikan } \\
\text { dan mampu membuat modul yang inspiratif dengan } \\
\text { baik sesuai materi yang diberikan narasumber. }\end{array}$ \\
\hline 5 & Penutup & $\begin{array}{l}\text { Bagian akhir dilakukan pos tes untuk mengetahui } \\
\text { tingkat pemahaman peserta setelah pelatihan } \\
\text { dilakukan. }\end{array}$ \\
\hline
\end{tabular}

Melalui tabel 2, Di sini bisa di pahami hasil dari kegiatan pengabdian (PKM) yang dilakukan, softskills para peserta pelatihan Guru SMA dan SMPN di Kec. Pulau Pinang yang mengikuti pelatihan meningkat dengan sangat baik dan pelatihan berhasil dengan sangat baik, sehingga peserta pelatihan menjadi lebih optimis dalam menghadapi masa depannya ini memberikan keuntungan bagi siswa bagi peserta didiknya, karena masyarakat semakin percaya dan bagi STTP dengan pengabdian dan pelatihan ini mendapat calon atau peminat baru untuk kuliah di STTP dan lebih meningkatkan kepercayaan pada kemampuan alumni yang sangat baik. Kedua, penjelasan tentang pengantar membuat modul dan peserta memahami dengan baik materi yang disampaikan dan terbukti di bagian, Ketiga, Peserta memahami dengan baik dan mengaplikasikan (praktek) dengan baik materi yang disampaikan pada saat penyampaian materi teori, terakhir dilakukan lagi tes disebut pos tes dan hasilnya peserta $100 \%$ memahami dengan baik materi yang disampaikan, sehingga berdasarkan pengamatan bisa diidentifikasi berikut merupakan hasil akhir dari dilaksanakannya pelatihan, yaitu:

a. Para peserta pelatihan Guru SMP dan SMAN di Kec. Pulau Pinang mempunyai pengetahuan dan pemahaman yang baik tentang Pembuatan modul yang bagus.

b. Para peserta pelatihan Guru SMP dan SMAN di Kec. Pulau Pinang memahami dengan baik tentang teknologi informasi khususnya Ms. Word.

c. Guru peserta sudah terbantu dalam pemberian pemahaman terhadap teknologi informasi up to date yang aplikatif.

d. Para peserta pelatihan lebih memahami lagi tentang aplikasi pembelajaran TIK, berdasarkan multimedia yang ada pada word.

e. Para peserta pelatihan menjadi lebih merasa percaya diri saat terjun pada masyarakat.

\section{KESIMPULAN}

Pelaksanaan pengabdian masyarakat (PkM) ini yang dilakukan bagi Guru SMP dan SMAN di Kec. Pulau Pinang didapatkan kesimpulan sebagai berikut:

a. Membantu para guru pelajaran TIK dalam hal memahamkan Guru Non TIK terhadap suatu aplikasi tertentu, yang aplikatif.

b. Melaksanakan proses pembelajaran dengan cara belajar aplikasi secara langsung ternyata sudah mampu meningkatkan semangat siswa belajar menjadi lebih baik (giat).

c. Menambah softskills para Guru di SMP dan SMAN Kec. Pulau Pinang bidang TIK.

d. Meningkatkan rasa percaya diri Guru dengan kemampuannya ketika terjun di masyarakat. 


\section{SARAN}

Maka sesuai pengalaman yang dilihat dan dirasakan pengabdi saat melakukan pengabdian ini maka, penulis dalam hal ini bisa memberikan saran:

a. Aplikasi yang diajarkan lebih variatif, agar peserta tidak bosan.

b. Waktu pelatihan lebih panjang

\section{UCAPAN TERIMA KASIH}

Terima Kasih semuanya.

\section{DAFTAR PUSTAKA}

[1] Abdillah, L., Handayani, T., Rosalyn, E. R., \& Mukti, Y. I. (2020). Collaborating Digital Social Media for Teaching Science and Arabic in Higher Education during COVID-19 Pandemic. Ijaz Arabi: Journal of Arabic Learning, 4(2), 12-25.

[2] Arif, A., \& Mukti, Y. (2017). Rancang Bangun Website Sekolah Menengah Pertama (SMP) Negeri 8 Kota Pagar Alam. JURNAL ILMIAH BETRIK: Besemah Teknologi Informasi dan Komputer, 8(03), 156-165.

[3] Muslim, B. 2018. Pelatihan aplikasi editing video dengan filmora., Laporan Pengabdian Kepada Masyarakat, LPPM STT Pagaralam.

[4] Muslim, B. 2018. Pelatihan Pembuatan Blog Bagi Guru Ma Ponpes Darul Mutaqin Kota Pagaralam. NGABDIMAS. Vol 1. No.1. Bulan Juni, Hal. 6-11

[5] B. Muslim, Pengantar teknologi informasi. Yogyakarta: Deepublish, 2017.

[6] Muslim, B. (2018). Analisis system informasi (SI) terintegrasi di Perguruan Tinggi (PT) (Studi Kasus: STT Pagaralam). Jurnal Teknologi Informasi MURA, Vol 10. Page 83-91.

[7] Muslim, B (2014). Analisis rencana aplikasi teknologi informasi pada STT Pagar Alam. Proseding semnastik dan Magma. Issue: Aplikasi Teknologi dan sistem Informasi. PPP UBD Pres. Pages 397-404.

[8] Hutchinson E. Sarah and Sawyer C. Stacey, 2000, Computers, Communications \& Information, McGraw Hill Companies Inc.

[9] Indonesia Services Education HP Tim, 2001, Manajemen Sistem Belajar Di Dunia Maya, Majalah Info Komputer.

[10] M.H Jogiyanto, 1995, Pengenalan Komputer, Andi Offset Yogyakarta.

[11] Horsley, M., Knight, B., \& Huntly, H. 2010. The role of textbooks and other teaching and learning resources in higher education in Australia: Change and continuity in supporting learning. IARTEM 1-Journal. 3(2). 43-61.

[12] Sadiman, A.S., Rahardjo, R., Haryono, A., \& Rahardjito. 2006. Media pendidikan: Pengertian, pengembangan, dan pemanfaatan. Jakarta: Rajagrafindo Persada.

[13] Menristekdikti. 2016. Panduan Pelaksanaan Penelitian dan Pengabdian Masyarakat di Perguruan Tinggi Edisi X Tahun 2016. hlm. 4

[14] Isro'Mukti, Y. (2017). Sistem Informasi Madrasah Aliyah Negeri Pagar Alam Berbasis Web. Indonesian Journal of Computer Science, 6(2), 192-205.

[15] Mukti, Y. (2017). Perencanaan Strategis Sistem Informasi Dan Teknologi Informasi Pada Sekolah Menengah Kejuruan Negeri 2 Pagar Alam. JURNAL ILMIAH BETRIK: Besemah Teknologi Informasi dan Komputer, 8(02), 83-92.

[16] Isro'Mukti, Y. (2018, October). Sistem Informasi Manajemen Aset Sekolah Tinggi Teknologi Pagaralam Berbasis Web. In Seminar Nasional Teknologi Informasi dan Komunikasi (SEMNASTIK) (Vol. 1, No. 1, pp. 632-638).

[17] Mukti, Y. (2018). Rancang Bangun Website Sekolah Dengan Metode User 
Centered Design (UCD). JURNAL ILMIAH BETRIK: Besemah Teknologi Informasi dan Komputer, 9(02), 84-95.

[18] Mukti, Y. (2018). Pelatihan Maintance Komputer SMAN Pagar Gunung. NGABDIMAS, 1(1), 47-51.

[19] Mukti, Y. I. (2019). Implementasi Jaringan Hotspot Kampus Menggunakan Router Mikrotik. Indonesian Journal of Computer Science, 8(2), 130-138.

[20] Mukti, Y. I., \& Puspita, D. (2019). Sistem Informasi Peringatan Dini Bencana Pada Kota Pagar Alam Berbasis Mobile. Jusikom: Jurnal Sistem Komputer Musirawas, 4(2), 65-74.

[21] Mukti, Y. I. (2019). SISTEM INFORMASI MONITORING KESEHATAN MASYARAKAT BERBASIS WEB MENGGUNAKAN METODE UNIFED MODELLING LANGUAGE. Jusikom: Jurnal Sistem Komputer Musirawas, 4(1), $1-8$.

[22] Mukti, Y. I., \& Puspita, D. (2019, December). Web Based Disaster Early Warning System on Pagar Alam City. In Conference SENATIK STT Adisutjipto Yogyakarta (Vol. 5, pp. 309-316).

[23] Isro'Mukti, Y., \& Puspita, D. WEB BASED DISASTER EARLY WARNING SYSTEM ON PAGAR ALAM CITY.

[24] Mukti, Y. (2020). Aplikasi Management Surat Pada Dinas Kesehatan Kota Pagaralam Menggunakan Codeigniter. JURNAL ILMIAH BETRIK: Besemah Teknologi Informasi dan Komputer, 11(2), 108-115.

[25] Mukti, Y. I. (2020). SISTEM PREDIKSI LULUS TEPAT WAKTU TUGAS AKHIR MAHASISWA MENGGUNAKAN SUPPORT VECTOR MACHINE (SVM). JUTIM (Jurnal Teknik Informatika Musirawas), 5(2), 110-115.

[26] Puspita, D., \& Isro'Mukti, Y. (2019, December). Web-Based Culture Information System of Literature Besemah City of Pagar Alam. In Conference SENATIK STT Adisutjipto Yogyakarta (Vol. 5, pp. 303-308). 